\title{
Colors as a semiotic tool for Bible analysis
}

\section{Introduction}

The article presents a new and complex approach to colors in the Bible. The demonstration of the method requires defining the distinction between verbal and visual color as feasible sign systems. No such distinction has been made up to now. This method serves one major goal: a better understanding of biblical texts originally given in Hebrew, with a focus on hermeneutics. A subsidiary aim is the disclosure of the various structures of color presence in biblical texts. This also involves a detailed semiotics of color, including a complex method based on both the achievements of other scholars and a specific proposal to treat colors as a language, as a sign system. The semiotics of color in the Bible includes four principal areas: color as a sign in general, color semiotics in the Bible and their specificities in both Hebrew and translations in different languages. As a case study, the article focuses on one verse, Song 1:5 , treated as a "semiotic iceberg," i.e., a structure with a visible semantic level supported by "submerged" or less apparent ones. ${ }^{1}$ Presenting this method cannot be short and simple because, on the one hand, it is complex, holistic and interdisciplinary, and on the other, there are many novelties in the analysis, including new terms and hypotheses that we must connect with existing terminology in color research. As such, we provide clarification for a number of terms, such as verbal and visual colors as signs, color language and color speech, semio-osmosis, color as a cultural unit, the inner form of the word, mega-color, basic color terms (BCT), prototype Terms (PT), rivals for prototypes (RT) and basic features of prototypes (BFPT).

1 More examples for the application of the method (Almalech 2011b, 2012a, 2012b, etc.) can be found at Academia.edu https://newbulgarian.academia.edu/MonyAlmalech and at https://in dependent.academia.edu/MonyAlmalech. 


\section{The method}

\subsection{Color language and color speech: Visual and verbal color language}

Current scholarship focuses on colors in multimodal texts or messages in an attempt to formulate a visual communication grammar. Kress and van Leeuwen (2002) deal with visual color by analyzing color speech and visual rhetoric, but not verbal language about color. According to them, color is metafunctional in Halliday's terms $(1978 ; 1993)$ with ideational, interpersonal and textual functions. Sometimes, color fulfills these three metafunctions simultaneously (346), but color does not always fulfill all three functions (350). Kress and van Leeuwen recognize that there are two ways to produce color meaning. The first is psychological: by associations that come from culture and the past, but also present-day advertising and brands. An important element is the context in which an association operates. The second way is to accept visual qualities of color-hue, saturation, purity, modulation, differentiation-as semantic distinguishing features, which appear within ideational, interpersonal and textual functions (355).

Thus, we consider physical properties of color first, in the territory of natural language, and second, in social and individual cultures and tastes. This means that we can hardly find a specific color grammar for an entire society. Van Leeuwen holds that "[1]ooking at color as a semiotic resource means [...] focusing on its materialities and technologies." $(2011,1)$. This means, in my terms, to focus on the "speech apparatus" of humankind regarding producing color-signs. Van Leeuwen declares that "looking at color as a semiotic resource not only means looking at color technologies, it also means looking at the way color meanings are developed." (2). Van Leeuwen is concerned with the possibility that colors may indicate ideas and feelings, which I consider essential in the semiotics of color.

An important semiotic study is the motivation of the color sign. Van Leeuwen provides historical details (2), although not in comparison with natural language where the linguistic sign is arbitrary, except for a small number of onomatopoeic words. Along with this, there are many important features of the motivation and the ability to make completely subjective interpretations of color idiolect or color dialect positions. In the examples from my corpora (Almalech 2001; 2011a), there are facts I treat as important features in color language:

- The same color can have opposite meanings. I call this intra-color antonymy.

- Many colors can mean the same feeling or idea. This is inter-color synonymy. 
- Both effects are due to the small number of tokens in the color language visual and verbal.

Volli ([1988] 1990) deals with colors in fashion showing that semiotic change is the basic rule. Leone (2007) reviews different semiotic instruments for the analysis of color. He proposes the idea that the qualities of visual color - hue, saturation, purity - present an array of distinguishing features. This opinion is similar to that of Kress and Van Leeuwen's (2002) but with certain differences, since he does not use systemic linguistics. For understanding the language of colors, it is necessary to analyze the semantic function of these three elements and the combinations of all of them "in the common sense" of features "tint," "shade" or "the synecdoche color" (164). The physical properties of visual color hue, saturation, purity, etc., should be understood as distinguishing features in terms of phonology-in the structural version of Leone's semiotics and the systemic linguistics methodology of Kress and van Leuwen. However, in my opinion, such properties are irrelevant to natural language and color meanings of righteousness, sinfulness and illness.

Semioticians deal with the translation of colors-from verbal to visual. Kourdis (2017) explicitly speaks of such translations in advertisements. Leone (2009) presents a semiotic interpretation in the art of Marc Chagall of Moses receiving from God the Tablets of the Law. He indicates how the visual colors match the biblical text. Caivano (1998) also is concerned with the visual aspect of colors, but without using the methodology of systemic linguistics. He advocates making "[S]emioticians interested in visual semiotics better acquainted with the very elaborate aspects of color theory, from which they could take models to develop other aspects of visual semiotics, and to make color theorists more familiar with general semiotics" (390). An important related question is, "Are there shared meanings between visual and verbal colors?" I present a list of such shared meanings in Almalech (2011a). Treating colors as cultural units, as Eco ([1985] 1996) does, gives more freedom and chances for reflecting on the constantly elusive non-color meanings of colors (visual or/and verbal). We should note that Eco implies relationships between visual and verbal color.

\subsection{The B\&K tradition and mega color: Color as a cultural unit and mega-color}

Over the past fifty years, Berlin and Kay's Basic Colour Terms: Their Universality and Evolution (1969) has stimulated discussion and given a greater prominence to basic color terms (BCT). The Berlin and Kay (B\&K) tradition (Berlin and Kay 
1969; Kay and Maffi 1999) uses the term macro-color (macro-white, macro-red, macro-grue, etc.). Macro-color deals with basic color categories (BCC), which are categories of the visual level of the human senses. A macro-color appears in connection with warm and cool categories, e.g., macro-red unites red, orange, yellow and warm, while grue includes green, blue, gray and cool. Macro-color is a "composite category." It may be represented by different basic color terms (BCT), and vice versa (Witkowski and Brown 1977, 50). These categories are related to the primary colors in human biology, as in opponent process theory. However, the prototypes of colors are never part of the B\&K tradition.

While the B\&K tradition focuses only on basic color terms (BCT), my method includes all four channels referring to color: basic color terms (BCT), prototype terms (PT), rival terms for prototypes (RT) and terms for basic features of prototypes (TBFP). This unity is mega-color: mega-white, mega-black, mega-green, etc. Colors expressed in the biblical text occur within four different kinds of lexemes, i.e.; within the channels BCT, PT, RT and TBFP. In the B\&K tradition, BCC's are presented only by BCTs. However, anthropological data show that in different cultures BCCs are presented by PT or RT (see, for example, Borg 1999 and 2007).

The word mega is appropriate for many reasons but mainly to avoid any confusion with the Berlin and Kay tradition. To avoid confusion and scientific uncertainty, I will use the terms mega-black, mega-white, mega-red, etc., but not macro-black, macro-white, macro-red, etc.

The mega-color category includes:

- All possible linguistic ways to refer to a color (e.g., black) in different cultures and languages: basic color terms (BCT), prototype terms (PT), rival terms for prototypes (RT) and terms for the basic features of the prototypes (TBFP). Examples for different members of mega-Black are: BCT black, be black, PT darkness, coals (according to Rosch 1972a, 1972b, 1973; Wierzbicka (1990), RT, e.g., raven, shadow, ebony, apple of the eye and TBFP, e.g., obscurity.

- The mega-color category includes distinguishing the feature "warm-cold" in the sense of Kay and Maffi (1999, 744): "Distinguish the warm primaries (red and yellow) from the cool primaries (green and blue)."

- BCT, PT, RT and TBFP form a cultural unit, in the sense of Eco (1996).

- The ultimate result of color perception is the sensation of color according to Hering's theory or Helmholtz's theory. In this sense, the mega-color category stands close to the macro-color category but differs in that the mega-category includes anthropological, psychological and cultural aspects of colors.

- BCTs are context-independent-they always mean color, while PTs could mean warm (for fire, blood, the sun at midday), cool (for darkness, sky, 
sea), fresh (for all plants), wide, spacious (for the sky and sea), e.g., they are context-dependent. RTs and TBFPs have strong context dependence.

Lakoff pointed out the complexity of colors, and his opinion is close to the mega category in my terms:

Color concepts are embodied in that focal colors are partly determined by human biology. Color categorization makes use of human biology, but color categories are more than merely a consequence of the nature of the world plus human biology. Color categories result from the world plus human biology plus a cognitive mechanism that has some of the characteristics of fuzzy set theory plus a culture-specific choice. (Lakoff 1987, 29)

My conviction that the semiotics of color should include all four channels (BCT, PT, RT and TBFP) in a verbal sign system and treating colors encyclopedically as cultural units corresponds to Sutrop's (2011) observation that "focusing research only on the BCTs minimizes the linguistic, semantic and semiotic richness of a color language. [...] BCTs form the absolute minority (maximally 0.5 to 5 percent) of the color terms in a language. We can paraphrase Lotman's formula in the following way: color language $=$ BCTs and non-BCTs + history of language and culture" $(46-47)$.

There have been two scholarly monographs dealing with color in the Old Testament: Athalya Brenner (her dissertation of 1979, published as a book in 1982) and John Hartley (2010). Both authors know Hebrew and both start with a review of the paradigm of Berlin and Kay (1969), including its development in Berlin and Kay's World Color Survey (WCS). The prime object of both authors is BCTs. Brenner briefly mentions “objects of typical color," i.e., RT, while for Hartley an important aspect is the comparative analysis of Hebrew BCTs with Semitic and Indo-European languages. Gershom Scholem's text (1979-1980) illuminates important aspects of Hebrew color terms in the Jewish tradition without reference to the B\&K method.

Mega-color includes words referring to color but not visual colors, while cultural unit color should include both visual and verbal colors. As Eco said,

When one utters a color term, one is not directly pointing to a state of the world (process of reference), but, on the contrary, one is connecting or correlating that term with a cultural unit or concept. The utterance of the term is determined, obviously, by a given sensation, but the transformation of the sensory stimuli into a percept is in some way determined by the semiotic relationship between the linguistic expression and the meaning or content culturally correlated to it. $(1996,160)$

To read a sacred text through color means to present a linguistic worldview. This worldview, which should also be thought through problems of translation, can 
both be preserved and/or changed. And this shows the importance of linguistics and culture.

Color as a cultural unit should include problems of linguistics, semiotics and Hebraic studies if we talk about color in the Bible, verbal and visual colors, color and non-color meanings (lexical and contextual) and the entirety of information on semantics of verbal and visual colors-synchronic and diachronic, cultural and social. Color as a cultural unit should include meanings of visual and verbal colors in folk and religious rituals.

Color language covers non-color meanings of visual and/or verbal color: 1 . In novels, we have words for colors; 2. In rituals, colors are visual; 3. Both are categorized with non-color meanings and some of these meanings are similar.

Eco (1996) calls the non-color meanings of colors "values" (174). For me, these "values" are the principal goal of semiotics of color. To reach this goal is very difficult because it needs many preconditions, clarifications and an enormous scientific apparatus. We should take into account folklore and religious culture-in both diachronic and synchronic directions. In short, a large personal encyclopedia. Until (2011a), I abstained from using the term “cultural unit” about color because properly decoding the semantic values of colors requires a large personal encyclopedia. "Values" like hope, health, love, etc. are relevant in novels and rituals. How does it happen that for flags "the system of basic values to be expressed by colors is a limited one," but for rituals and novels, it is not so limited?

Despite the many contributions hitherto, there has been no clear differentiation of the semiotic statuses of visual and verbal color. Eco (1996) points out the difference and, at the same time, the connection between visual and verbal colors: "We are dealing with verbal language so far as it conveys notions about visual experiences, and we must, then, understand how verbal language makes the non-verbal experience recognizable, speakable and effable” (159).

The Prototypes (light, milk, or snow for White; darkness and/or coals for Black, etc.) are visual nature objects valid for all peoples, regardless of political and economic systems and social structure, and the degree of technological development. They are a universal phenomenon based on human anatomy and the environment. Studies of the rituals of different peoples give one reason to think about a small number of universal values, motivated by the strategy of ritual and its relationship with color prototypes. Just as diachronic changes are the mien of permanent semiosis for natural languages, changes in the language of color during the centuries are something we can expect to happen. 


\subsection{Translation as a criterion and semiotic value; Semio-osmosis: Black $\leftrightarrow$ Dark; Green $\leftrightarrow$ Grass; Green $\leftrightarrow$ Fresh}

Equalization between BCTs and PTs is a process which can also be called semioosmosis. This metaphor is appropriate because translators try to equalize the sense and the meaning of two languages. The goal of semio-osmosis is equalizing the worldviews between the target and the source languages. The septum/ membrane that translators must overcome is the different worldviews and grammars of the two languages. Often, it is impossible to translate a word in the same derivative string as in the source language. A typical example is the derivative string of the Hebrew root Aleph-Dalet-Mem. In Hebrew, man, Adam, ground, red, Edom, blood, ruby are derivatives linked to this one root. The ultimate effect of semio-osmosis is to keep the original meaning, according to the cultural habits and linguistic parameters of the carriers of the target language.

Semio-osmosis flows between Hebrew and a translation, passing on the vehicle of the prototypes, their most typical features and some culturalizations. Most English translations (e.g., KJV, NKV) of Job 30:28 render the Hebrew black [kodèr] as go about mourning or go about in gloom instead of go about blackened.

The ultimate goal of semio-osmosis is the highest equality of texts. In this sense, accommodation and semio-osmosis are opposite processes. In fact, the authors of key translations adhere more to semio-osmosis, despite inter-linguistic asymmetry, dissymmetry, the difference of worldviews, cultural differences and traditions.

The BCT green is more frequently used in translations than in the Hebrew text. If we add the "green" translations of grass, leaf and meadow, many more uses of BCT green are registered in translations than in the Hebrew original. Is this a mistake? Does this change the meaning, the sense and the holy text?

Equalization between BCTs and Terms for the Basic Features of Prototypes (TBFP) also appears in translations. The sum of Hebrew BCT green in different forms ([ièrek], [iaràk], [iarokà] and the diminutive [ierakràk]) is 11 times, while the BCT green appears (with tiny differences among different translations) about 30 times in translations.

In Hebrew, the word fresh [raanàn] is an attribute of tree 11 times, fresh tree [etz raanàn]. Fresh [raanàn] is an attribute also of olive and leaf in Song 1:16: "Behold, thou art fair, my beloved, yea, pleasant: also our bed is green.” (KJV); "How handsome you are, my lover! Oh, how charming! And our bed is verdant." 
(NIV) The universality of prototypes and their most typical qualities overcome difference between worldviews.

The Septuagint is highly important, not only as the first translation of the Hebrew Bible in another language, but also it was made by Jewish priests and represents Alexandrian Judaism. Badgers, Hebrew [tahashìm] is translated in Septuagint v́akívөıvoৎ (hyacinth-color, dark blue). Bulgarian and Russian Orthodox versions follow the Septuagint with син, синий (blue). If somebody suffers from ignorance of the history of translations, he/she says that in the Bible there is no color in the noun phrase badgers' skin [or tahashìm], but it will be Anglocentrism or Catholic-, or Protestant- centrism, depending on the translation the reader uses. I have such experience with specialists in color names who claimed that there is no color in verses where Hebrew [or tahashìm] is translated as badgers' skin. They followed the English version of the Bible they are familiar with, where there are no blue skins, but badgers' skins. Such an evaluation of a biblical text shows a lack of culture for a history of translations and a specialist in color naming suffering from mother-tongue centrism. It could be any language-centrism caused by the lack of encyclopedic knowledge, in Eco's terms.

A similar case obtains with blue [tehèlet] and purple [argamàn]. We cannot understand their functional and sacral semantics if we do not know that the dyes signified by these terms must be produced from sea creatures, murex trunculus but nothing else. The same is with scarlet [tolàat šani], where the word [tolàat], is the case-form of Hebrew word worm [tolà].

\subsection{Biblical colors are a text within a text}

Lotman's idea of the text within the text (1994) is very appropriate to the system of verbal colors, although Lotman applied it to art:

The text within the text is a specific rhetorical construction in which the determining factor in the author's construction of the text and in the reader's reception of it is the differential codification of various parts of the text. The transition from a semiotic system of textual comprehension to a system of internal structural boundaries constitutes the basis for the generation of meaning. (Lotman 1994, 380)

Lotman points out the great complexity of texts within any civilization, and that this issue is "closely connected to the problem of the text's relation to its cultural context” (380). Further, “[c]ulture in its entirety may be considered a text-a complexly structured text, divided into a hierarchy of intricately interconnected text within texts. To the extent that the word text is etymologically linked to weaving, the term's original sense has been restored" (384). 
Lotman's idea is appropriate in several aspects. Colors present a "differential codification of various parts of the text" (380). In natural language, as a leading communicative sign system, visual knowledge for the prototypes of colors and their local and universal non-color meanings are interwoven. The "transition from" the semiotic system of a natural language providing "textual comprehension" of an internal system of color "structural boundaries constitutes the [...] generation of meaning" (380). The basic feature of the color text within the texture (including genres, stories, chapters, books, etc.) of the Bible is that in the reader's minds the non-color meanings come and work at the subconscious level. Finally, "internal" boundaries of color structure result in "demarcating different levels of codification" (380).

We can say that the color system in the text is an internal structure with "boundaries" which are "mobile" but the boundaries depend on the worldview matrix of Hebrew and languages of translation. Hebrew has one color text within the biblical text, based on root derivations. Indo-European languages have a different color text. Correspondingly, the color text in Hebrew presents another logical and theological space, e.g., the first man אָדָָ [adàm], Adam [àm] is red אָדָדָמָה [ָד [adòm], as the ground he was made of (Gen 2:7), blood דָ אדָ אדָם [dam] andem] are part of Creation....

The color text within the biblical text depends on the general problem "of the text's relation to its cultural context" (Lotman 1994, 380). An important element of the "text's relation to its cultural context" is the inter-linguistic asymmetry and dissymmetry which swims in the ocean of cultural traditions as folklore, philosophy (e.g., Plato) and material culture. At the same time, color structure, being coded in its verbal version, remains based on visual knowledge and its culturalization, i.e., the color text within the biblical text is "doubly coded": "in the simplest occurrence the included section is encoded in the same way as the remaining text and thus is doubly coded" (381).

Unlike the literary text analyzed by Lotman, where the "authentic subtext within the rhetorical unity of the text is to create the semblance of reality" (382), the subconscious color text has two directions. The first one serves the conscious flow of the "rhetorical unity of the text" as the color of something. The second one is the system of one color that flows through the entire text of the Bible, and the color is encoded to build a color text within the complete text. For example, in the Hebrew Bible, there are only nine uses of BCTs for Black. This statistically poor appearance is a sign that needs decoding. These nine Hebrew BCTs for black are situated in the context of about 1000 uses of the PT (darkness) as a tool to refer to black color, overgrown with luscious metaphorical, metonymic, theological and artistic meanings. 


\subsection{Statistics for different color words have important semantic and semiotic values. BCT sequence.}

Bankov $(2017,121)$ points to Eco's opinion that "an encyclopedic competence is based on cultural data which is socially accepted on the basis of the statistical constancy of its occurrence" (Eco 1979, 18). For Bankov this sentence "unlocked" Eco's interpretative semiotics. Bankov is right that the quotation integrates the Peircean doctrine of infinite semiosis with Eco's theory of the open text, which "relies quite diligently on some of the key notions of Greimassian semiotics" (121). In a way, this statement bridges two previously mutually impervious universes-that of Peirce and of structural textual analysis. Bankov's statement (121) gives an interpretative and hermeneutic value to colors as a cultural unit: "[T]his is the only place (and only in the Italian version of the book) where the expression 'statistical constancy' is used, and obviously this exact formulation was necessary to unlock the hermeneutic circle. [...] The encyclopedic model of culture-based on the principle of the statistical constancy of the occurrence of cultural units."

Color presence in the Old Testament is a cultural unit, in Eco's terms, in two directions:

- The BCT root paradigms are not the same as the root paradigms of Indo-European color terminology. The Hebrew root paradigms of BCTs are dissymmetrical or asymmetrical with respect to Indo-European worldviews, being an untranslatable categorization of the world and of thinking based on it. We have unique cultural aspects of the understanding of the Hebrew text by Hebrew readers and Indo-European readers. (This does not apply to biblical scholars of all nations familiar with the biblical text and culture.) This happens although the translations are correct, adapted and accommodated.

- If we need color presence completeness, we must check BCTs, PTs (e.g., light, darkness, sun, fire, blood, sky, sea, all plants), RTs (e.g., linen, cherry, duckling, ruby, wine, sapphire) and TBFPs (e.g., clean, pure, immaculate for light; hot, warm for fire; fresh for plants, etc.).

Both Eco's idea of color as a cultural unit and mega-color should include statistical data on different words referring to color. The semiotic value of statistics of BCTs, PTs and RTs has many implications: it gives a notion of the big picture of the Bible text-its history, and structure; a structural scheme of contextual semantics which is the other side of the coin of the semiotics of colors; the extended semantics of Hebrew roots which in Hebraic tradition is a tool for interpretation, but in modern terms the Hebrew worldview is a hermeneutic tool for decoding the original messages of Hebrew texts. 
Statistics as a semiotic tool is important for BCTs because they are contextindependent and always signify color. Frequency is not the main direction of my method but only insofar as it has semiotic value. The frequency of BCTs in the Old Testament is relative to Hebrew and not to translations, because translations do not reflect Hebrew facts due to the work of translators who sometimes translate Hebrew BCTs with Indo-European PTs and vice versa. The Hebrew BFPTs fresh, well-watered (plant) and moist are very frequently translated with the English BCT green. From a semiotic point of view, not only the highest frequencies but also cases of hapax legomena are important.

In my study of BCT in the novels of three Bulgarian popular writers from the second half of the 20th century (Almalech 2001), white, black and red have the highest frequency. These three colors are the only ones in the culture of the Ndembu tribe (Turner [1966] 2004). This corresponds to the first three BCTs in the evolution of languages according to Berlin and Kay (1969).

In the Hebrew Bible, the situation is very different. The most frequently used are the three BCTs from the color tetrad of blue, crimson and purple (the fourth member of the sacral color tetrad being an RT, flax). They are followed by white, then red, then green-ten uses. Black has only nine uses throughout the Old Testament. For yellow, the Old Testament has no BCT.

We could expect that the Primordial BCT (White and Black) should be the most frequent and appear first in the text. The facts indicate the opposite. BCT-Black is used only nine times and it appears for the first time after the first appearance of any other of the BCTs. As we know from linguistics, a lack of a sign is a sign. An indirect aspect of these statistics is the sequence of BCTs and it can be compared with the Berlin and Kay (1969) sequence. Sometimes the first and last appearances of BCT or PT have semiotic and hermeneutic values.

The following table is compiled according to the Berlin and Kay (1969) sequence compared to the first appearance of BCTs in the Bible. The sequence in the project "Semiotics of Colors in the Bible" traces the first appearance of BCTs in the biblical text, where Scarlet and Purple are under mega red, and black-1 [shahòr], dark/brown [hum] are under mega black. I avoid the grue of WCS. 
Table 1: BCT sequence according to Berlin and Kay (1969) and in the Bible first use of BCTs

\begin{tabular}{|c|c|c|c|}
\hline & $\begin{array}{l}\text { Berlin and Kay } \\
\text { (1969) BCTs }\end{array}$ & & Hebrew Bible BCTs \\
\hline I & $\begin{array}{l}\text { Black \& White (Dark } \\
\text { \& Light) }\end{array}$ & I & Green יוּרק [ierek] (Gen 1:30) \\
\hline II & Red & II & 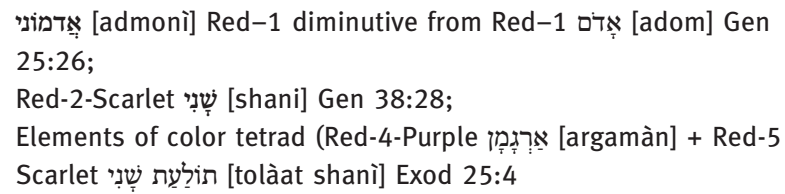 \\
\hline III & Green/Yellow & III & Dark/Brown חוּם [hum] Gen 30:32 \\
\hline IV & Green/Yellow & IV & White לָבָן [lavan] Gen 30:35 \\
\hline $\mathrm{V}$ & Blue & $\mathrm{V}$ & תבְכְלֶת [tekhelet] Exod 25:4 \\
\hline VI & Brown & $\mathrm{VI}$ & Dark/Brown חוּם [hum] Gen 30:32 \\
\hline- & - & & Black-1 שָחוֹר [shahòr] Lev 13:31 \\
\hline VII & $\begin{array}{l}\text { Orange, Pink, Pur- } \\
\text { ple, Gray }\end{array}$ & VII & - \\
\hline
\end{tabular}

The first to appear is green (Gen 1:30), the second is Red-1, reddish אִדמוֹ [admonì] (Gen 25:26) diminutive of Red-1, אָדם [adòm] (Gen 25:30), the third is

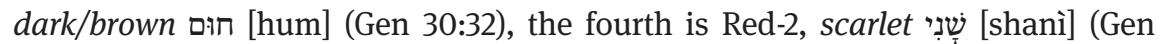
38:28), the fifth is white לבָ [lavàn] (Gen 30:35), sixth is the hapax Red-3/Dark,

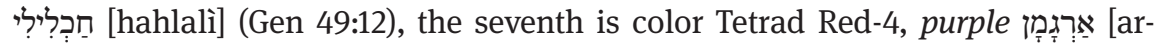

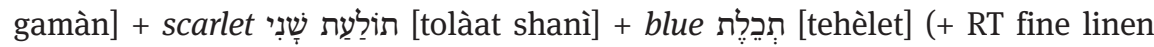
[shesh], Exod 25:4) and the last is the most common BCT Black-2 [shahor] (Lev 13:31).

Such a sequence does not match completely the B\&K academic paradigm associated with the BCT evolution hypothesis in its 1969 version. The version of 1999 also does not correspond to the biblical sequence because the most common term for Black appears last, eighth in frequency while the 1999 version covers five levels.

\subsection{Conclusions}

The B\&K method excludes PT, PT and BFPT from the study object. This is inappropriate for the Hebrew worldview, at least because of the words red, ground, man, a blood, Adam, Edom, mankind and ruby derivational string are linked in one logical, mental and theological unit by their mutual root Aleph-DaletMem. In terms of Jewish culture, every word and letter are important as a 
God's message and any delicate change is unacceptable. The process of translation includes semio-osmosis, but the practice includes accommodation both replacing Hebrew BCT (black) with Indo-European PT (darkness) or Hebrew BFPT (fresh) with Indo-European BCT (green) or Hebrew PT (darkness) with Indo-European BCT (black). The symbolism of colors in every culture is based on universal prototypes.

Decoded structures of Hebrew color terms and semiotic data serve a better understanding of original Hebrew semantics, worldview and biblical context because much remains hidden in Hebrew. Better understanding presupposes the hermeneutic value of the method. This holistic approach merges a psycholinguistic test and the theory of prototypes to reveal the links between visual and verbal colors.

I consider translation from Hebrew to be an element of the semiosphere, e.g., the Septuagint exhibits an attempt to present the Hebrew worldview within the worldview of the Greek language, as well as the cultural traditions of Hellenism and Alexandrian Judaism.

Leone (2019) pointed out "the most convincing suggestions for semiotic color analysis come essentially from the semiotics of visual texts" (163). The method I put forward for consideration is a development of the semiotics of verbal color as language (langue) not speech (parole).

\section{A semiotic iceberg}

\subsection{Introduction}

The metaphor of an iceberg is appropriate because one verse contains a large number of colors, of which only one is explicit ("visible"), while seven others are implicit ("invisible"). Song 1:5 illustrates various manifestations of megacolor in the Bible. The iceberg is an appropriate metaphor for the Hebrew text, which has "visible" and "invisible" parts for most Indo-European readers on account of inter-linguistic symmetry and asymmetry. This does not pertain to biblical scholars familiar with the biblical text and culture. We also need Jewish and biblical cultural information for recognizing colors.

I analyze the verse according to the Hebrew worldview. Colors are in one explicit (visible) part/level while three other parts/levels are "underwater" or invisible to most readers coming from an Indo-European linguistic background. The term level reflects the possibility for recognizing the color and its symbolism. The harder it is to capture symbolism and colors, the lower or more "submerged" the level. 
Our objects of consideration are the basic color term black שִחרוֹרָה [shehorà] and the comparisons "like the tents of Kedar, like the curtains of Solomon." For a skilled reader of the Pentateuch, the multi-colored parts/levels (tents, Kedar and curtains, i.e., three of the "invisible" parts/levels), are comprehensible because cultural knowledge is needed but not a Hebrew worldview. The goal is to present the original Hebrew biblical meanings for most contemporary readers with IndoEuropean linguistic backgrounds.

\subsection{The semiotic iceberg in more detail}

The verse contains four color messages. The explicit (visible) part of the semiotic iceberg is the basic color term black שִחוֹרָה [shehorà] because it completely corresponds to the Indo-European BCT black in distinct languages. This is due to inter-lingual symmetry. The visible in Indo-European languages terms are $\mu \varepsilon^{\prime} \lambda \alpha \mathrm{l}-$ vó (Greek), nigra (Latin) black (English), nera (Italian) noire (French), schwarz (German), черна (Bulgarian), чорна (UKR), черна (RST). It is the first or highest and the "visible" level of the semiotic iceberg.

Song 1:5

שחוֹרה אני ונאוה בנוֹת ירושלים כהלי קדר כיריעות שלמה

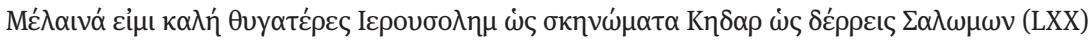
nigra sum sed formonsa filiae Hierusalem sicut tabernacula Cedar sicut pelles Salomonis (1:4 VUL)

I am black, but comely, $\mathrm{O}$ ye daughters of Jerusalem, as the tents of Kedar, as the curtains of Solomon. (KJV)

I am black, but comely, Oh ye daughters of Jerusalem, As the tents of Kedar, As the curtains of Solomon. (ASV)

I am black but lovely, O daughters of Jerusalem, Like the tents of Kedar, Like the curtains of Solomon. (NAS)

I am black and beautiful, $\mathrm{O}$ daughters of Jerusalem, like the tents of Kedar, like the curtains of Solomon. (NRS)

Io sono nera ma bella, o figlie di Gerusalemme, come le tende di Kedar, come le cortine di Salomone. (LND)

Je suis noire, mais je suis belle, filles de Jérusalem, Comme les tentes de Kédar, comme les pavillons de Salomon. (LSG)

Je suis noire, moi, mais jolie, filles de Jérusalem, comme les tentes en poil sombre (the tents in dark hair) comme les rideaux somptueux. (TOB)

Ich bin schwarz, aber gar lieblich, ihr Töchter Jerusalems, wie die Hütten Kedars, wie die Teppiche Salomos. (LUO)

Черна съм, но хубава, ерусалимски дъщери, Като кидарските шатри, като Соломоновите завеси (BUL1, BUL2)

Дочки єрусалимські, я чорна та гарна, немов ті намети кедарські, мов занавіси Соло- 


\section{монові! (UKR)}

Дочери Иерусалимские! черна я, но красива, как шатры Кидарские, как завесы Соломоновы (RST Song of Solomon 1:4)

For the ancient Hebrews, blackness was an unusual association with beauty. "[I] n high circles beauty is associated with a ruddy, shiny or glowing complexion“ (Hartley 2010, 76). The prophet describes the beauty of David with the BCT red אָד [adòm] (1Samuel 16:12) translated as ruddy in English: "So he sent and had him brought in. He was ruddy, with a fine appearance and handsome features. Then the LORD said, Rise and anoint him; he is the one." Bulgarian translations accommodate this to pyc ("blond").

Most of the translations use the corresponding BCT for black, but there are exceptions. The English dark, Italian scura "dark" and Portuguese morena "dark" equalize the Hebrew BCT with a Prototype term (PT). The German BCT braun changes the color or pretends that the Hebrew BCT שִׁחוֹ [shehorà] refers to black but also brown. The Spanish morena ("brunette") replaces the original Hebrew BCT black, an exceptional term for designating beauty, with a more common beauty term expressed by an RT, brunette.

Dark am I, yet lovely, O daughters of Jerusalem, dark like the tents of Kedar, like the tent curtains of Solomon. (NIB)

I am very dark, but comely, O daughters of Jerusalem, like the tents of Kedar, like the curtains of Solomon. (RSV)

Sono scura ma bella, o figlie di Gerusalemme, come le tende di Chedar, come i padiglioni di Salomone. (NRV)

Ich bin braun, aber gar lieblich, ihr Töchter Jerusalems, wie die Zelte Kedars, wie die Teppiche Salomos. (LUT)

Eu estou morena e formosa, ó filhas de Jerusalém, como as tendas de Quedar, como as cortinas de Salomão. (ARA)

Morena soy, oh hijas de Jerusalem, Mas codiciable; Como las cabañas de Cedar, Como las tiendas de Salomón. (SRV)

The above-mentioned multilingual translations of the Hebrew black שִׁחוֹ [shehorà] with brown, brunette, etc. can be treated as accommodations but also as sharing Sasson's opinion that "in the cultural milieu of the Near East in modern times-and ancient times-a black complexion (to make a generalization) cannot be so beautiful that it inspires love songs, certainly not a literary masterpiece like the Song of Songs. I therefore think the lady in the Song was 'dark' and not 'black' of complexion. It should be remembered at this point that the issue is not mere dark complexion but dark beauty" $(1989,413)$.

The invisible (implicit) layers of the semiotic iceberg remain below the IndoEuropean worldview "waters." Comparisons such as like the tents of Kedar and 
like the curtains of Solomon are not very clear to today's readers because they are not elements of modern culture and require insight into the ancient cultures and symbols. In the general case, they remain implicit (invisible).

\subsection{Tents of Kedar}

This noun phrase contains two directions for color associations for carriers of Hebrew and Jewish culture. The first direction is the name of the tribe Kedar קָדָר [kedàr]. It involves in a semi-explicit manner dark, black. It is "first" level because it reduplicates the blackness in the verse due to relation to the root Kuf-Dalet-Reish K-D-R קדר:

Table 2: Regular root semantics of Kuf-Dalet-Reish

\begin{tabular}{ll}
\hline $\begin{array}{l}\text { 1. to mourn, mourn, grieve; 2. to be dark } \\
\text { dark, black }\end{array}$ & [kadàr] \\
darkness, gloom & קָדר [kadrùt] \\
\hline
\end{tabular}

Bible dictionaries and encyclopedias do not deal with the meanings "nice" or "pleasant" of the root Kuf-Dalet-Reish, K-D-R קדר. According to TWOT and ISBE, the Kedar tribe inhabited the Arabian Peninsula and made tents of skins. In the Jewish understanding, there is an association with the Tabernacle. Bulgarian translations make use of the word хубава ("beautiful"), while in English, the preferred terms are comely and lovely, and in French they are belle ("beautiful"), jolie ("pretty"), etc.

If the Biblical Hebrew term for this tribe is the proper name Kadar, then the members of the tribe seemed to have dark skin or some other dark feature, important for the Hebrew worldview. ${ }^{2}$ The proper name reflects a logical feature, which lies at the basis of any word or so-called "inner form," in Humboldt's (1883) terminology.

The inner form presents an appropriate approach to proper names such as Edom ("red"), the twin brother of Jacob/Israel; Lavan ("white"), the father-inlaw of Jacob/Israel and many other biblical proper names. Perhaps the tribe of Kedar called itself by a different name, but in the Hebrew text, this proper

2 On the Internet, there is an opinion I do not share: the tribe "lived in black-hair tents" (Song 1:5). A quick Google search shows many sites repeating this assertion uncritically. The source seems to be Matthew George Easton's Illustrated Bible Dictionary (1893). Although it's an out of date source, its public domain status may be responsible for this opinion being widespread. 
name is a reflection of the Hebrew worldview and linguistic and cultural habits. Thus, Kedar is a reduplication of blackness by a Prototype Term (PT) dark.

The other direction lies in the word tents. Decoding this requires an excellent knowledge of the Pentateuch and Jewish culture. Tents comprise a completely implicit level of the invisible parts of the semiotic iceberg for Indo-European speaking non-specialists in biblical topics. We do not know what the colors of the tents among the Kedar tribe were. The word tent in the verse is אהל [ohèl]. It is one of the terms for the Tabernacle, which remained a term also for the buildings of the First and the Second Temple. This term [ohèl] is one of the other several terms for the temple, e.g., [mishkàn], a dwelling place of God. Gesenius (1996) notes: "To the distinction in the tabernacle, between [ohèl] and [mishkàn], [ohèl] denoted the exterior covering, consisting of twelve curtains of goats' hair, which was placed over the proper dwelling [mishkàn], i.e., the twelve interior curtains or hangings which lay upon the frame-work; see Ex[od] 26:1;7;36; 8:14; 19:2.” (18).

The Septuagint omits the word tent, replacing it with "dwelling-place” $\sigma \kappa \eta$ -

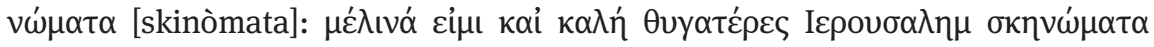

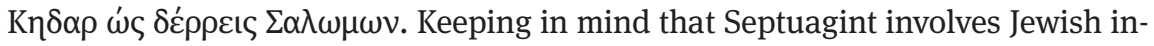
terpreters, it is possible to think they emphasized another notion of the Temple, which is the Hebrew [mishkàn] dwelling place, but not to the temple אהקל [ohèl]. Thus, they emphasize the holiness of the relations between Solomon and the black Shulamite, which also exists in the Hebrew text. This invisible for Indo-European non-specialists in biblical topics is the presence of the idea that the love between Solomon and Shulamite is a sacral space, as in the case of the Temple.

The outer covering of the Tabernacle tent are different red and blue skins: red [adumìm] goats' skins and blue (badgers'/dolphin) skins (Num 4:5-15). This is a color dyad. The Septuagint interpretation of badgers' (dolphin; seal) skins

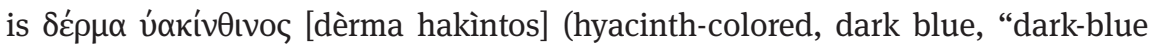
skins"), i.e., the focus is on the color and not the material of the outer covering of the Tabernacle tent. Later, Protestant and Catholic versions translate the term literally as badgers' (dolphin) skins, in accordance with the Hebrew term [or tahàsh], while most Orthodox versions follow the Septuagint tradition with blue skins (кож синего цвета RST; сини кожи BUL2). If a Hebrew reader has not seen processed dolphin skin, he will not see a color dyad on the Tabernacle's exterior. The Vulgate used ianthinarum pellium ("violet sealskin"):

Num 4:6

And shall put thereon the covering of badgers' skins [...] (KJV)

and shall put thereon a covering of sealskin [...] (ASV)

Then they are to cover this with hides of sea cows [...] (NIV) 


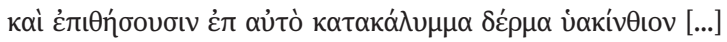
et operient rursum velamine ianthinarum pellium extendentque desuper pallium totum hyacinthinum et inducent vectes (VUL)

и положат на нее покров из кож синего цвета [...] (RST)

и да турят отгоре й покривката от сини кожи [...] (BUL2)

\subsection{Curtains of Solomon}

I connect the third invisible (implicit) level to the term curtains. It comes fourth if we count the visible level of BCT שִחוֹרֵה [shehorà]. This invisible level is also multi-colored.

In the temple interior, the curtains divide the Holy of Holies of the grand hall. Solomon keeps the colors of the curtains in the First Temple. There is no description of the curtains in Solomon's palace in the Bible. Therefore, the association is with the curtains in the Temple. The twelve interior curtains in the temple are in four colors - blue, purple, scarlet and white. This tetrad of sacral colors is categorized by special terms: blue [tehèlet], purple [argamàn], scarlet [tolàat shani], and fine linen [shesh]/[butz]. The skins of the exterior of the Tabernacle tent are different reds and blues: red [adumìm] and blue (badgers'/dolphin). For Song of Solomon 1:5, NIB presents a strange direction using like the tent curtains of Solomon. It is an oxymoron for the tent is a term for the Tabernacle, but Solomon builds a temple of "stone and wood."

The meaning and significance of the whole verse encompasses both the regular text and the semiotic iceberg. For an Indo-European speaking reader, the meaning remains clear enough. For the Hebrew speaking addressee, the whole verse can be compared to an iceberg with multiple levels and color based cultural meanings.

The verse is a kind of threat to the daughters of Jerusalem-the beauty of a black woman is unacceptable according to tradition, but in this case, this black beauty must not be hindered but should be perceived as a sacred space for the association with the tent of the temple and the colors of Solomon curtains. Thus, love between Solomon and Shulamite is like a sacral space which should be honored and not impeded. The Daughters of Jerusalem must not forget that Solomon is the king, and if they oppose his love for the Shulamite, they will face the Sacred.

Can we consider the meaning and the significance of the whole verse as constituting a fifth level? It depends on individual styles and preferences. 


\subsection{Conclusions}

If we expand the metaphor of the iceberg, it has visible (explicit) and invisible (invisible) parts/levels/layers. The semiotic iceberg includes one recognizable level of BCT black for Hebrew and Indo-European readers and the three invisible ones for Indo-European readers who are non-specialists in biblical topics. The visible and one invisible (semi-visible) levels are related to mega-black, expressed with BCT black and a proper name derived from PT dark, Kedar. Two of the invisible (implicit) levels are the color tetrad of curtains and the color dyad at the tent. The color tetrad and dyad are comprehensible for any Indo-European skilled expert of the Pentateuch.

The individual reader can shift the levels if the color connection of Kedar with darkness is clear. If for someone the curtains are a clear carrier of colors and sacredness, then the levels can be shifted again. My logic is that Kedar precedes Solomon's curtains in the word order.

The next recognized level could be the warning to the daughters of Jerusalem that they respect the sacred love between the black Shulamite woman and Solomon the Jewish leader.

The semiotic iceberg needs a large encyclopedia, in Eco's terms, to see and decode correctly the existence of the phenomenon at many levels.

The idea for levels illustrates the mega-color approach, e.g., distinguishing the means of a color through different terms (BCT, PT), expressing different cognitive abilities for expressing color.

The root Kuf-Dalet-Reish acquires association of this type of darkness with grief, mourning and several explicit and implicit context semantizations of unpleasant feelings, experiences, conditions and states. Here, the root has an atypical context-dependent meaning-beauty, pleasantness.

Explicit and implicit colors are part of the richness of Song of Solomon, reminiscent of the popular view that holds Song of Songs to be the most esoteric of the entire canon (Dennis 2009).

I hope the color semiotic iceberg of a verse reveals a small piece of the hidden content of Song of Songs.

\section{General conclusions}

The greatest difficulty in defining the parameters of the verbal color language is the connection with visual perception and visual color speech. However, the connection between prototypes and the verbal language of colors is the culturalization of prototypes. Culturalization takes place in the mind and subconscious, 
passes into rituals and finally into natural languages through categorization with basic color terms, prototype terms, rivals to prototype terms and the second most important quality (pure for White, fresh for Green, warm for Red, infinity for Blue) of a prototype. The contexts in which the various words signify color are also important.

The semiotic iceberg partially reveals the power of this method. The concept of mega-color includes the idea of color as a cultural unit, while also taking into account Jewish culture, which includes diachrony of the Hebrew language and the sacredness of the Bible. Mega-color takes into account translations, the semio-osmosis process, reiteration of ritual, statistics on the frequency of BCTs and PTs, the first use of a BCT as a rhematic use of color. The method includes the outlining of color structures as text within text and the symbolic connections between the Old and New Testaments characterized by unity regardless of the different stages of Hebrew and the Greek text of the New Testament. Although a small fragment, the semiotic iceberg is an example of the abundance of color-related semiotic values and demonstrates the effectiveness of the method.

The semiotic iceberg illustrates a small fragment of the depths of the Hebrew worldview and the original content of the Old Testament.

\section{References}

Almalech, Mony. 2001. Цвят и слово. Прагматични и психолингвистични аспекти. [Colour Language and Natural Language: Psycholinguistic and Pragmatic Aspects.] Sofia: Marin Drinov Academic Publishing House.

Almalech, Mony. 2011a. Advertisements: Signs of femininity and Their Corresponding Colour Meanings. Sofia: Marin Drinov Academic Publishing House.

Almalech, Mony. 2011b. "The Eight Kinds of Linen in the Old Testament." Lexia, Journal of Semiotics, new series. Special issue: Immaginario. 7-8: 325-64.

Almalech, Mony. 2012a. “What Does 'Psalm' Mean in Hebrew?" Lexia, Journal of Semiotics, new series, special issue: Worship, 11-12: 153-73.

Almalech, Mony. 2012b. "Biblical Windows." Gramma: Journal of Theory and Criticism, special issue: Semiotics as a Theory of Culture: Deciphering the Meanings of Cultural Texts, 20: 93-104.

Bankov, Kristian. 2017. "Eco and the Google Search Innovations." In Eco in his own words, edited by Torkild Thellefsen and Bent Sørensen, 119-26. Berlin: De Gruyter Mouton.

Berlin, Brent and Paul Kay. 1969. Basic Colour Terms: Their Universality and Evolution. Berkeley: University of California Press.

Borg, Alexander. 1999. "Linguistic and ethnographic observations on the color categories of the Negev Bedouin." In The Language of Colour in the Mediterranean, edited by Alexander Borg, 121-47. Stockholm: University of Stockholm.

Borg, Alexander. 2007. "Towards a History and Typology of Colour Categorization in Colloquial Arabic.“ In Anthropology of Colour: Interdisciplinary Multilevel Modeling, 
edited by Robert MacLaury, Galina Paramei, and Don Dedrick, 263-93. Amsterdam: John Benjamins Publishing Company.

Brenner, Athalya. 1982. Colour Terms in the Old Testament. Sheffield: JSOT Press.

Brenner, Athalya. 1979. "Colour Terms in the Old Testament." A thesis submitted to the University of Manchester for the degree of Ph.D. in the Faculty of Arts, 1979, Department for Near East Studies.

Caivano, Jose. 1998. "Color and Semiotics: A Two-way Street." Colour Research and Application 23 (6): 390-401.

Dennis, Geoffrey. 2009. "Song of Songs: The Secret Meaning is the Plain Meaning." Jewish Myth, Magic, and Mysticism. 13 December 2009. http://ejmmm2007.blogspot.com/2009/12/song-of-songs-allegory-is-plain-meaning.html

Eco, Umberto. 1979: Lector in Fabula. Milano: Bompiani.

Eco, Umberto. (1985) 1996. "How Culture Conditions the Colours We See" In The communication theory reader, edited by Paul Cobley, 148-171. New York: Routledge.

Gesenius, William. (1847) 1996. Hebrew-Chaldee Lexicon to the Old Testament. $18^{\text {th }}$ edition. Boston: Crocker and Brewster.

Halliday, Michael. 1978. Language as Social Semiotic. London: Arnold.

Halliday, Michael. 1993. Language in a Changing World. Canberra: ALAA Occasional Paper 13. Hartley, John. 2010. The Semantics of Ancient Hebrew Colour Lexemes. Louvain; Peeters. Humboldt, Wilhelm von. (1883) 1971. Die sprachphilosophischen Werke. Edited by Heymann Steinthal. Berlin: Ferd. Dümmlers Verlagsbuchhanlung Harrwitz und Grossman.

Kay, Paul and Luisa Maffi. 1999. "Colour Appearance and the Emergence and Evolution of Basic Colour Lexicons." American Anthropologist, 101 (4): 743-60.

Kourdis, Evangelos. 2017. "Colour as Intersemiotic Translation in Everyday Communication: A Sociosemiotic Approach.“ In Proceedings of the 12th World Congress of the International Association for Semiotic Studies, Sofia 2014, 16-20 of September, New Bulgarian University, edited by Kristian Bankov, Ivan Kasabov, Mony Almalech, Borislav Georgiev, George Tsonev, Reni lankova, Dimitar Trendafilov, Ivo Iv. Velinov, Yagodina Manova, and Boyka Buchvarova, 736-46. Sofia: NBU Publishing House \& IASS Publications.

Kress, Gunther and Theo van Leeuwen. 2002. "Colour as a Semiotic Mode: Notes for a Grammar of Colour." Visual Communication 1 (3): 343-68.

Lakoff, George. 1987. Women, Fire, and Dangerous Things. Chicago: The University of Chicago Press.

Leone, Massimo. 2007. "Strumenti semiotici per lo studio dei colouri." In Squillacciotti. Sguardi sui colouri: Arti, Comunicazione, Linguaggi, edited by Massimo Leone, 163-74. Siena: Protagon editori.

Leone, Massimo. 2009. "La Legge e il Coloure - Analisi semiotica di alcune incisioni di Marc Chagall.“ In Testure - Scritti seriosi e schizzi scherzosi per Omar Calabrese, edited by Stefano Jacoviello, et al., 61-90. Siena: Protagon Editori.

Leone, Massimo. 2019. "Semiotics of Religion: A Map." American Journal of Semiotics 35 (3/4): 309-33.

Lotman, Yuri. 1994. "The Text within the Text." Translated by Jerry Leo and Amy Mandelker. PMLA 109, no. 3 (May): 377-84. https://doi.org/10.2307/463074.

Rosch, Eleanor 1972a. "Probabilities, sampling, and ethnographic method: The Case of Dani Colour Names." Man, new series 7: 448-66. 
Rosch Eleanor 1972b. "Universals in Colour Naming and Memory." Journal of Experimental Psychology 20-10:(1) 93.

Rosch, Eleanor 1973. "Natural Categories.” Cognitive Psychology 4: 328-50.

Sasson, Victor. 1989. "King Solomon and the Dark Lady in the Song of Songs." Vetus

Testamentum 9 (4): 407-14.

Scholem, Gershom. 1979-1980. "Colours and Their Symbolism in Jewish Tradition and Mysticism.” Diogenes Part I 1979, 27 (57): 84-111; Part II 1980, 28 (64): 64-76.

Sutrop, Ulmas. 2011. "Towards a Semiotic Theory of Basic Colour Terms and the Semiotics of Juri Lotman." In New Directions in Colour Studies, edited by Carole Biggam, Carole Hough, Christian Kay, and David Simmons, 43-6. Amsterdam: John Benjamins Publishing Company.

Turner, Victor (1966) 2004. "Colour Classification in Ndemby Ritual.” In Anthropological Approaches to the Study of Religion, edited by Michael Banton, 47-84. London: Routledge.

Van Leeuwen, Theo. 2011. Language of Colour: An Introduction. London: Routledge. Volli, Ugo. (1988) 1990. Contro la Moda. Milano: Feltrinelli.

Wierzbicka, Anna. 1990. "The Meaning of Colour Terms: Semantics, Cultures and Cognition." Cognitive Linguistics 1 (1): 99-150.

\section{Abbreviations}

\section{Bibles Dictionaries and Encyclopedias}

ISBE - International Standard Bible Encyclopedia. 5 vol. set, (1915) 1939. James Orr (general ed.) Wm. B. Eerdmans Publishing Co; 1915. Chicago: Howard-Severance Co. Online: https://www.internationalstandardbible.com/S/seraphim.html

TWOT - The Theological Wordbook of the Old Testament by Laird Harris, Gleason Archer, Bruce Waltke. Illinois: Moody Press. (1980) 2003. BibleWorks 4. 1989 LLC. Montana: Hermeneutika, Big Fork.

\section{Bibles, Translations}

\section{Cyrillic}

BUL1 Bulgarian Protestant Version 1940, 1995, 2005

BUL2 Bulgarian Orthodox Version 1925, 1991

RST Russian Synodal Text of the Bible (1996) 1997

UKR Ukrainian Orthodox Version 


\section{English}

ASV American Standard Version 1901

KJV King James $(1611,1769)$ 1997-1998

NAS (NASB) New American Standard Bible 1977

NIB New International Version UK 1983

NIV New International Version 1984 (US)

NRS New Revised Standard Version 1989

RSV Revised Standard Version (1952) 1971

\section{French}

LSG The French Louis Segond Version (1910) 1988-1997

TOB French Traduction Oecuménique de la Bible 1988

\section{German}

LUO The German Luther Bibel (1912) 1995

LUT Revidierte Lutherbibel 1984

\section{Greek}

LXX Septuagint. Retrieved from http://biblehub.com/interlinear/; BW

\section{Hebrew}

Biblia Hebraica Stuttgartensia 1990

\section{Italian}

LND The Italian La Nuova Diodati 1991

\section{Latin}

VUL Latin Vulgate 


\section{Portuguese}

ARA The Brazilian Portuguese João Ferreira de Almeida, Revista e Atualizada, 2nd edition 1993

\section{Spanish}

SRV - Versión Reina-Valera 1909 [1997-1998]

\section{Bible software}

BW - Bible Works 4. 1989 LLC. Montana: Hermeneutika, Big Fork. 